\title{
Utilization of food sources by invertebrates in a man-made intertidal ecosystem (Westerschelde, the Netherlands): a $\delta^{13} \mathrm{C}$ and $\delta^{15} \mathrm{~N}$ study
}

\author{
Pascal Riera* ${ }^{\dagger \ddagger}$, Lucas Stal ${ }^{\dagger}$ and Joop Nieuwenhuize ${ }^{\dagger}$ \\ *Station Biologique de Roscoff, Université Pierre \& Marie Curie Paris VI-CNRS, Place Georges-Teissier, BP 74, \\ 29682 Roscoff cedex, France. ${ }^{\dagger}$ Centre for Estuarine and Marine Ecology, Netherlands Institute of Ecology-KNAW (NIOO-CEME), \\ Postbus 140, 4400 AC Yerseke, The Netherlands. ${ }^{\ddagger}$ Corresponding author, e-mail: riera@sb-roscoff.fr
}

The trophic interactions between primary consumers and the organic matter sources in a man-made intertidal ecosystem were investigated. The most representative invertebrates that occupied the different habitat types tend to use similar food sources, namely benthic diatoms and suspended particulate or sedimentary organic matter, although they do so in different proportions. Fucus vesiculosus was abundant on the rocky substrate but this macroalga nor its epiphytes contributed importantly to the diet of the primary consumers inhabiting these assemblages. In contrast, benthic diatoms from the nearby mudflat were directly used as a food source because of their re-suspension in the water and transport by the tide to the artificial rocky shore. The results suggested that the trophic pathways in this intertidal environment were relatively simple.

\section{INTRODUCTION}

Many intertidal ecosystems have been modified through engineering works and other anthropogenic activities. Such changes can alter trophic interactions in benthic communities that inhabit these ecosystems. In order to determine the primary producers that contribute mostly to the flows of carbon and nitrogen in intertidal food webs, the use of stable isotopes has been shown to be particularly useful. For example, it was shown that in the estuarine ecosystem of the Plum Island Sound that included different food sources (e.g. fresh and salt marsh plants, microphytobenthos), benthic consumers relied preferentially on the most locally produced source (Deegan \& Garritt, 1997). Moreover, co-occurring food sources can also be used by different invertebrate species. Likewise, benthic diatoms, macro-algae, terrestrial derived organic matter, and phytoplankton in the intertidal area of the mouth of the Charente estuary (France) were used by different co-occurring benthic invertebrates (Riera \& Richard, 1996).

The Westerschelde is an example of a turbid and eutrophic tidal estuary delivered by the River Schelde, which drains an area with one of the highest population and industry densities in Europe. The intertidal areas of the mid-Westerschelde estuary include artificial rocky shores (i.e. dykes and stone deposits) and mudflats. Although the importance of microphytobenthos as a food source for the invertebrates inhabiting these intertidal mudflats was recently pointed out (Herman et al., 2000), the sources used by the invertebrates occurring on the artificial rocky shores and on the nearby intertidal mudflats remains poorly understood.

The aim of the present study was to investigate the trophic interactions in an artificial man-made ecosystem of intertidal mudflats bordered by artificial rocky substrates and dykes.

\section{MATERIALS AND METHODS}

The sampling site was an intertidal mudflat limited by stone deposits and a dyke along the shore of the Westerschelde estuary, locally known as the Biezelingse Ham $\left(51^{\circ} 56.47^{\prime} \mathrm{N} 3^{\circ} 55.51^{\prime} \mathrm{E}\right)$. Sampling was carried out from January to February 1998. Water samples (10 l) were collected from about $20 \mathrm{~cm}$ below the water surface during high tide. Within $2 \mathrm{~h}$, suspended particulate organic matter (POM) was collected by filtration on precombusted $\left(6 \mathrm{~h}, 550^{\circ} \mathrm{C}\right)$ Whatman $\mathrm{GF} / \mathrm{F}$ filters. The filters were acidified $(1 \mathrm{M} \mathrm{HCl})$ to remove carbonates. After being rinsed with Milli-Q water, the filters were lyophilized and stored desiccated until analysis. Sediment samples from the mudflat were taken during low tide by scraping the upper $1 \mathrm{~cm}$ of mud for the analysis of the sediment organic matter (SOM). The sediment was lyophilized and ground to powder using a mortar and pestle.

Fucus vesiculosus, which was the dominant macroalga on the rocky substrates and dykes, was collected manually, cleaned of their epibionts, and washed with $1 \mathrm{MHCl}$ to remove carbonates. After being rinsed with Milli-Q water, the samples were lyophilized and ground to powder. Epiphytes of Fucus vesiculosus were collected by gently scraping the surface of the seaweeds in $\mathrm{GF} / \mathrm{F}$ filtrated seawater. Microscopic analysis showed that the material collected consisted mostly of epiphytic microorganisms and sediment particles. The epiphytic organic matter was collected by filtration on pre-combusted Whatman GF/F and treated as described above. Benthic 
Table 1. $\delta^{13} C$ and $\delta^{15} \mathcal{N}$ (range of values) of POM, SOM, sources of organic matter and intertidal invertebrates in the Westerschelde (The Netherlands) during winter 1998. n, number of individuals or samples.

\begin{tabular}{lccc}
\hline & $\delta^{13} \mathrm{C}$ & $\delta^{15} \mathrm{~N}$ & $\mathrm{n}$ \\
\hline Sources & & & \\
SOM & -24.7 to -24.0 & 8.2 to 9.0 & 8 \\
POM & -24.7 to -23.8 & 8.1 to 8.2 & 2 \\
Benthic diatoms & -18.0 to -15.6 & 15.9 to 19.2 & 4 \\
$\begin{array}{l}\text { Fucus vesiculosus } \\
\text { Epiphytes }\end{array}$ & -22.4 to -20.5 & 23.0 to 28.5 & 2 \\
$\begin{array}{l}\text { Terrestrial Gramineae } \\
\text { Gastropoda }\end{array}$ & -21.0 to -20.1 & 17.7 to 20.5 & 4 \\
$\begin{array}{l}\text { Littorina littorea } \\
\text { Bivalvia }\end{array}$ & -15.8 to -14.7 & 18.4 to 20.6 & 4 \\
$\begin{array}{l}\text { Crassostrea gigas } \\
\text { Cerastoderma edule }\end{array}$ & -22.0 to -20.9 & 19.1 to 20.5 & 5 \\
$\begin{array}{l}\text { Oligochaeta } \\
\text { Lumbricillus sp. }\end{array}$ & -18.7 to -18.0 & 18.0 to 19.4 & 3 \\
$\begin{array}{l}\text { Polychaeta } \\
\text { Nereis sp. }\end{array}$ & -21.0 to -20.1 & 17.7 to 18.5 & 5 \\
$\begin{array}{l}\text { Crustacea } \\
\text { Carcinus maenas }\end{array}$ & -16.7 & 19.6 & 1 \\
$\begin{array}{l}\text { Eulimnogammarus obtusatus } \\
\text { Corophium volutator }\end{array}$ & -19.1 to -18.3 & 17.5 to 23.7 & 6 \\
\hline
\end{tabular}

diatoms were collected at low tide by scraping the sediment surface and extracted according to the method of Couch (1989). The extracted diatoms were collected on pre-combusted Whatman $\mathrm{GF} / \mathrm{F}$ and treated as above. Terrestrial Gramineae, which were abundant at the upper levels of the dykes were collected by hand and prepared in the same way as macroalgae.

Individuals of Crassostrea gigas, and Littorina littorea were collected by hand on the rocky substrate. The amphipod Eulimnogammarus obtusatus was collected from the macroalgae assemblages. Cerastoderma edule, Nereis sp., Corophium volutator and Carcinus maenas were taken at low tide from the sediment surface. The oligochaete Lumbricillus sp. which was common at the sampling site was collected at low tide and extracted from the sediment samples using fine tweezers. Individuals were cleaned of epibionts and kept alive overnight in the laboratory in filtered seawater from the sampling site to allow evacuation of gut contents. Subsequently, the invertebrates were sacrificed by freezing and dissected from the shells (molluscs) or from the cuticle (crustaceans). The flesh was quickly acidified with $1 \mathrm{M} \mathrm{HCl}$ to remove any carbonate debris and rinsed with Milli-Q water. The samples were lyophilized and ground to powder using a mortar and pestle. Individuals of the oligochaetes and amphipods yielded too little tissue to allow for accurate isotopic analysis and therefore the material of four or five organisms was pooled. Harpacticoid copepods were extracted from 31 of sediment. In the laboratory, meiofauna was concentrated by passing the sediment cautiously through respectively a 500- and $125-\mu \mathrm{m}$ sieve in order to remove macrofauna, large particles, and to decrease the volume of sediment (Couch, 1989). The material retained on the $125-\mu \mathrm{m}$ sieve was used for the extraction of harpacticoids following the procedure of Couch (1989). The copepods were starved $12 \mathrm{~h}$ in $\mathrm{GF} / \mathrm{F}$ filtered seawater to clear the gut and rinsed

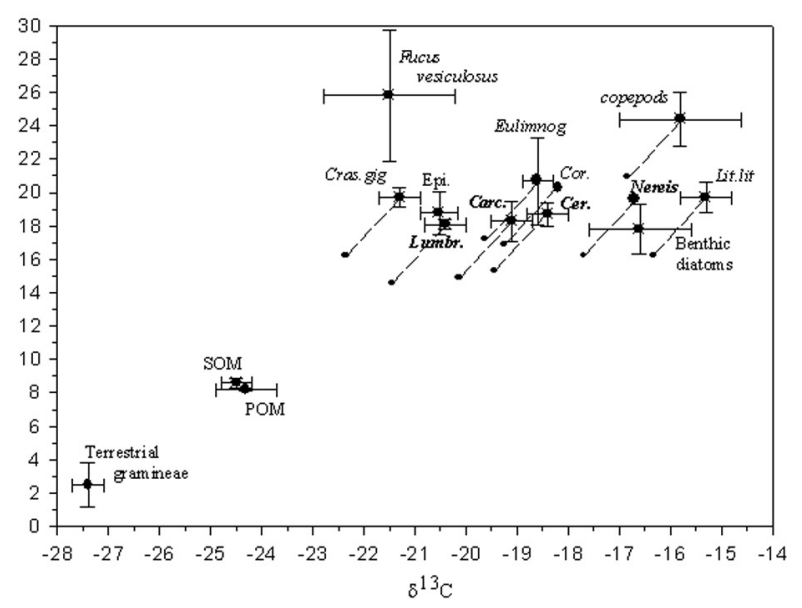

Figure 1. $\delta^{13} \mathrm{C}$ and $\delta^{15} \mathrm{~N}$ (mean standard deviation) of benthic invertebrates, suspended POM, SOM and the main sources of organic matter in the Westerschelde estuary. Fucus ves, Fucus vesiculosus, Epi., epiphytic community of $F$. vesiculosus, copepods, harpacticoid copepods, Lit.lit, Littorina littorina, Nereis, Nereis sp., Cer, Cerastoderma edule, Cor., Corophium volutator, Eulimnog., Eulimnogammarus obtusatus, Carc., Carcinus maenas, Lumbr., Lumbricilus sp., Cras gig., Crassostrea gigas. (•), average $\delta^{13} \mathrm{C}$ and $\delta^{15} \mathrm{~N}$ values corresponding to the theoretical food source of invertebrates taking into account the trophic enrichment of 1 and 3.4 for $\delta^{13} \mathrm{C}$ and $\delta^{15} \mathrm{~N}$, respectively; (- - -), trophic shift of carbon and nitrogen.

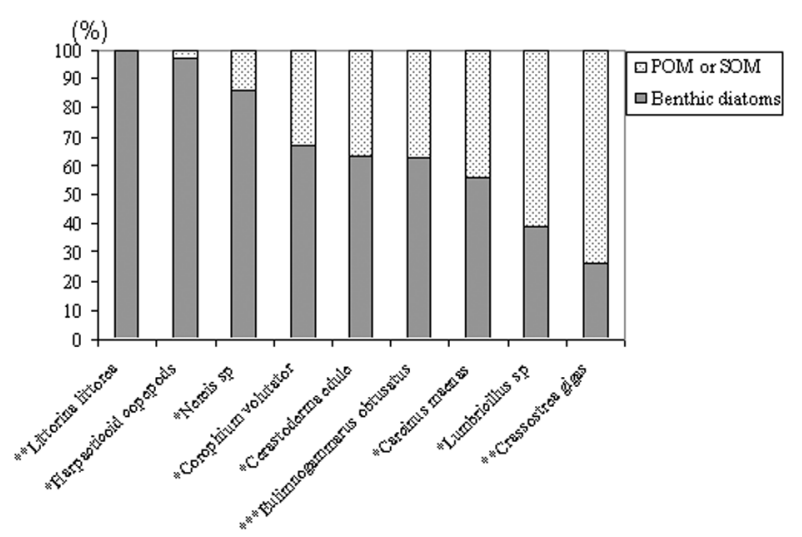

Figure 2. Estimation of the relative importance of carbon inputs from benthic diatoms and SOM or suspended POM to the different invertebrates, based on a two-source isotopic model equation. The three habitats from which the animals were collected, are indicated by the symbols: *, for sandymuddy sediments; **, for rocky substrates; and ***, for macroalgae assemblages, respectively.

before they were manually cleaned of any remaining contaminants using a dissecting microscope. Harpacticoids were then collected on pre-combusted Whatman $\mathrm{GF} / \mathrm{F}$ and treated as described above.

\section{RESULTS}

The range of $\delta^{13} \mathrm{C}$ and $\delta^{15} \mathrm{~N}$ for POM, SOM, primary producers and benthic invertebrates are presented in Table 1. The $\delta^{13} \mathrm{C}$ and $\delta^{15} \mathrm{~N}$ for SOM were similar to the corresponding values of POM, which strongly suggest that the suspended POM originated partly from the 
re-suspension of sediment. In particular, the $\delta^{15} \mathrm{~N}$ for benthic diatoms and Fucus vesiculosus was relatively high due to the incorporation of dissolved inorganic nitrogen of anthropogenic origin that is enriched in ${ }^{15} \mathrm{~N}$ and carried into the estuary by the River Scheldt (Riera et al., 2000). The epiphytic community of $F$. vesiculosus exhibited a mean $\delta^{13} \mathrm{C}$ vs $\delta^{15} \mathrm{~N}$ more enriched in ${ }^{13} \mathrm{C}$ and depleted in ${ }^{15} \mathrm{~N}$ than the organism.

A continuum of mean $\delta^{13} \mathrm{G}$ was found for benthic macrofauna, starting with Crassostrea gigas via Lumbricillus sp. and Nereis sp. to Littorina littorea (Figure 1). Intermediate $\delta^{13} \mathrm{C}$ values between Lumbricillus sp. and Nereis sp. were measured for Carcinus maenas, Eulimnogammarus obtusatus, Corophium volutator and Cerastoderma edule. The mean $\delta^{15} \mathrm{~N}$ for these invertebrates exhibited a smaller range of values (Figure 1). Harpacticoid copepods exhibited a mean $\delta^{13} \mathrm{C}$ and $\delta^{15} \mathrm{~N}$ of $-15.7 \pm 1.2$ and $24.4 \pm 1.5 \%$, respectively, hence, more ${ }^{15} \mathrm{~N}$-enriched than the macrofauna.

\section{DISCUSSION}

\section{Isotopic determination of food sources for intertidal invertebrates}

The main sources of organic matter possessed distinct $\delta^{13} \mathrm{C}$ vs $\delta^{15} \mathrm{~N}$ (Figure 1) which allowed their use to infer the food sources for the invertebrates. In order to identify the food sources for the benthic consumers, we considered a mean trophic enrichment in ${ }^{13} \mathrm{C}$ of 1 (DeNiro \& Epstein, 1978 ) and of $3.5 \%$ for ${ }^{15} \mathrm{~N}$ (Minagawa \& Wada, 1984) as a result of the assimilation of food (Figure 1). From these results, terrestrial organic matter was too ${ }^{15} \mathrm{~N}$-depleted and ${ }^{13} \mathrm{C}$-depleted to contribute significantly to the diet of the invertebrates considered. Similarly, Fucus vesiculosus was too ${ }^{15} \mathrm{~N}$-enriched as compared to the invertebrates to represent a major food source. Hence, the deposit-feeders showed a preference for a mixture of living benthic diatoms and SOM while the filter feeding invertebrates (i.e. Crassostrea gigas and Cerastoderma edule) used a mixed diet based on benthic diatoms and suspended POM. Then, a dual isotopic mixing model can be used to estimate the proportion of these sources incorporated by each of the invertebrate species.

\section{Use of isotopic mixing model}

The quantitative proportion of the main food sources incorporated by the consumers was based on a mixing model using $\delta^{13} \mathrm{C}$ values. In fact, $\delta^{15} \mathrm{~N}$ is not as powerful as $\delta^{13} \mathrm{C}$ for discriminating food sources, because of the lower range of the former and the overlapping of values for food sources and invertebrates, as shown previously in coastal ecosystems (Couch, 1989). The model assumes a proportional assimilation of different food sources and that the $\delta^{13} \mathrm{C}$ value becomes less depleted by 1 relative to the diet (De Niro \& Epstein, 1978). The proportion of carbon from benthic diatoms and suspended POM or SOM assimilated by invertebrates can be calculated using the equation:

$$
\delta^{13} \mathrm{C}_{\mathrm{animal}}=\left(\mathrm{P}_{\mathrm{b}}\right) \delta^{13} \mathrm{C}_{\mathrm{b}}+\left(\mathrm{P}_{\mathrm{pom}}\right) \delta^{13} \mathrm{C}_{\mathrm{pom}}
$$

where $\mathrm{P}_{\mathrm{b}}$ and $\mathrm{P}_{\text {pom }}$ are respectively the proportions of benthic diatoms and POM or SOM that contribute to animal diet, and $\left(\mathrm{P}_{\mathrm{b}}\right)+\left(\mathrm{P}_{\text {pom }}\right)=1$. In order to solve $\mathrm{P}_{\mathrm{b}}$ and $\mathrm{P}_{\text {pom, }}$, the mean carbon isotope values for benthic diatoms and POM or SOM, were fractionated by $1 \%$.

The results (Figure 2) indicated a decreasing feeding on living benthic diatoms from Littorina littorea (100\%) and harpacticoids $(97 \%)$ to oligochaetes $(39 \%)$ and C. gigas $(26 \%)$. The trophic link between the benthic diatoms and harpacticoid copepods provided further evidence for the importance of microphytobenthos for meiobenthic consumers inhabiting intertidal mudflats (Riera et al., 1996). Nereis sp. and Corophium volutator used a higher proportion of benthic diatoms compared to SOM (detritus) (respectively $86 \%$ and $67 \%$ ). Carcinus maenas used benthic diatoms and $\mathrm{SOM}$ in about the same proportion (respectively 56 and $44 \%$ ), consistent with the diversity of food sources of this organism. In contrast, Lumbricillus sp. used a higher proportion of SOM $(61 \%)$ compared to benthic diatoms $(40 \%)$. The isotopic position of $C$. edule suggested that this filterfeeding bivalve lived primarily on benthic diatoms (64\%) but, in addition, used also suspended POM (36\%). In fact, these food sources were directly available to C. edule, which inhabited close to the water-sediment interface. Eulimnogammarus obtusatus fed mostly on a mixed diet, which included benthic diatoms $(62 \%)$ and SOM $(38 \%)$. This contradicts previous reports that emphasized that intertidal amphipods inhabiting rocky shores behave as grazers on macroalgae (Pavia et al., 1999). The isotopic position of Crassostrea gigas indicates its preference for suspended POM $(74 \%)$ in addition to benthic diatoms $(26 \%)$. The ability of Crassostrea species to feed on benthic diatoms and to select for specific components of the organic matter pool has been observed previously (Riera \& Richard, 1996).

\section{Trophic interactions: impact of a man-made intertidal ecosystem}

Although these invertebrates inhabited different habitats (i.e. rocky substrates, muddy sediments, assemblages of macro-algae) and exhibited different feeding modes, the present study suggests that they depend on limited food source diversity. Particularly, L. littorina and $E$. obtusatus that occurred predominantly in the assemblages of $F$. vesiculosus, did not show any preference for the locally produced macroalgae biomass or its epiphytes. Their preference for benthic diatoms can be explained because (1) L. littorea also occurs on the mudflat and (2) the rocky substrates and macroalgae may become covered by mud and benthic diatoms due to wave action and tidal currents (P. Riera, personal observation). Hence, the organic matter originating from $F$. vesiculosus is most likely introduced into the estuarine food web as detritus through microbial transformations (Tenore et al., 1982). In contrast, microalgae which are more readily digestible for the invertebrates than macroalgae are likely to enter the intertidal food web directly.

Compared with other intertidal ecosystems, these present results suggest a simplification of the trophic interactions in this coastal area. Although several invertebrates possessed different feeding modes and occurred in different habitat types, they depended largely on one food source (i.e. benthic diatoms). This unexpected result may be explained by the typical characteristics of this manmade ecosystem. These included the low diversity of organic matter sources and their availability to invertebrates inhabiting the different habitats. Particularly, 
re-suspension and sedimentation of benthic diatoms growing on the intertidal mudflat became directly available to hard substrates communities. The study of trophic interactions may be expanded in other similar man-made coastal environments to confirm the trend observed in the Westerschelde estuary.

This work was financially supported by the European Commission contracts MAS3-CT97-5039 and MAS3-CT950022 (INTRMUD). We would like to thank Yvonne Maas for analytical and technical assistance. This is publication 3307 of NIOO-KNAW.

\section{REFERENCES}

Couch, C.A., 1989. Carbon and nitrogen stable isotopes of meiobenthos and their food resources. Estuarine, Coastal and Shelf Science, 28, 433-441.

Deegan, L.A. \& Garritt, RH., 1997. Evidence for spatial variability in estuarine food webs. Marine Ecology Progress Series, 147, 31-47.

DeNiro, M.J. \& Epstein, S., 1978. Influence of diet on the distribution of carbon isotopes in animals. Geochimica et Cosmochimica Acta, 42, 495-506.

Herman, P.M.J., Middelburg, J.J., Widdows, J., Lucas, C.H. \& Heip, C.H.R., 2000. Stable isotopes as trophic tracers: combining field sampling and manipulative labelling of food resources for macrobenthos. Marine Ecology Progress Series, 204, 79-92.
Minagawa, M. \& Wada, E., 1984. Stepwise enrichment of ${ }^{15} \mathrm{~N}$ along food chains: further evidence and the relation between $\delta^{15} \mathrm{~N}$ and animal age. Geochimica et Cosmochimica Acta, 48, 1135-1140.

Pavia, H., Carr, H. \& Aberg, P., 1999. Habitat and feeding preferences of crustacean mesoherbivore inhabiting the brown seaweed Ascophyllum nodosum (L.) Le Jol. and its epiphytic macroalgae. Fournal of Experimental Marine Biology and Ecology, 236, 15-32.

Riera, P. \& Richard, P., 1996. Isotopic determination of food sources of Crassostrea gigas along a trophic gradient in the estuarine bay of Marennes-Oléron. Estuarine, Coastal and Shelf Science, 42, 347-360.

Riera, P., Richard, P., Grémare, A. \& Blanchard, G., 1996. Food source of intertidal nematodes in the Bay of Marennes-Oléron (France), as determined by dual isotope analysis. Marine Ecology Progress Series, 142, 303-309.

Riera, P., Stal, L.J. \& Nieuwenhuize, J., 2000. Heavy $\delta^{15} \mathrm{~N}$ in intertidal benthic algae and invertebrates in the Scheldt estuary (The Netherlands): effect of river nitrogen inputs. Estuarine, Coastal and Shelf Science, 51, 365-372.

Tenore, K.R., Cammen, L., Findlay, S.E.G. \& Phillips, N., 1982. Perspectives of research on detritus: do factors controlling the availability of detritus to macroconsumers depend on its source? Fournal of Marine Research, 40, 473-490.

Submitted 5 October 2002. Accepted 9 January 2004. 